\title{
CAN RIGHTS BE THE UNDERLYING ASSETS OF SUKUK?: THE MALAYSIAN EXPERIENCE
}

\author{
Auwal Adam Sa'ad*
}

\begin{abstract}
Sukūk market has hitherto focused on issuances based on intangible underlying assets. Right (haqq) is intangible in nature which can in principle include government awards, goodwill, trademarks, receivables and other related rights as applied in the Islamic capital markets. This paper looks into the opinions of classical Muslim schools and scholars on whether or not these assets are acceptable assets for $s u k \bar{u} k$. The paper incorporates analysis of the current applications of right as an underlying asset for sukūk in Malaysia. The analysis includes a case study on $s u k u \bar{k}$ that uses right as an underlying asset, and raises some Sharī'ah questions surrounding its applications. The study stipulates that right is an eligible asset for $s u k \bar{u} k$ transactions, because it is valuable and capable of ownership and possession. However, it is recommended that $s u k \bar{u} k$ based on government award should only be issued by government entities; private companies should not issue sukūk based on government awards because it was based on iqta ${ }^{c}$ principle which only the government has the right to grant its ownership to the general public.
\end{abstract}

Keywords: Right; Underlying Asset; Șukūk; Sharī’ah

\section{INTRODUCTION}

Rights are intangible in nature; they could not be physically seen or touched as tangible assets. The shari'ah rules related to contract of sale of sukūk asset requires the subject matter to suit certain conditions on its legality, value, existence, and possible delivery. Sukük asset must be a valuable property that is capable of ownership and possession; it appears that certain assets that are used for suku $\bar{u} k$ transaction may not easily suite this requirement. The paper aims to examine issues related to financial rights by looking at the opinion of Muslim jurists from the four Islamic schools of jurisprudence, coupled with a case study of șukuk that experiences the use of right as an underlying asset for transaction.

\section{THEORIES ON RIGHTS (HUQUUQ $)$ UNDER ISLAMIC LAW}

The word haqq ${ }^{1}$ could be used to mean wealth and debt, as when Allah the Almighty said: "And let the one who has the obligation [i.e the debtor] dictate". ${ }^{2}$ $H a q q$ here means a debt or something established and proven. Huqūq as such refer to Shari' ah rulings related to a subject matter or its usufruct which can allow its owner to utilise from the usufruct or its outcomes". ${ }^{3}$ Kamāl bin Hammām 
defined it as a legal capacity given by the lawgiver for a usage except when it is otherwise restricted. ${ }^{4}$ Most of the definitions of haqq are thus related to the Lawgiver which indicate that the source of all haqq or ownership rights is the Almighty Allah and the Shari'ah as a manifestation of His will.

Selling a "right" or usufruct is a disputed issue amongst the Islamic scholars, Imām ibn 'Arafah from the Māliki school identifies bay' (sale contract) as a contract of exchange for a physical item that is not usufruct or pleasure. ${ }^{5}$ According to this definition lease, rent and marriage are not considered sale contracts as they are not physical objects. Imām al-Dasūki commented on this definition and said: "that means the sale contract can only occur on items that are not usufruct." Another definition has it that a sale contract consists of transfer of an asset for a return, while buying is to take over its possession. ${ }^{6}$ These definitions belong to scholars from the Māliki school. We can understand that according to them, the subject matter of a sale contract must be a physical item and not usufruct.

The Hanafi scholars are in harmony with Mālikis in prohibiting the sale of non-physical items and usufructs. However, they even excluded usufruct from the definition of property. Ibn 'Ābidīn has stated that it is essential in a sale contract that it should consist of exchange of property with another property, and usufructs are not regarded as property in the Hanafi School. By contrast, the Shāfi i School has developed the meaning of bay ' (sale contract) to mean the usufruct that could last forever, such as the right to sell the use of a road which is situated on other people's land, which is regarded as a valid sale contract according to Shāfi 'i School even if it is clearly a sale of usufruct. Imām Khațīb al-Sharbīnī from the Shāfi 'i school defines the sale contract as a contract of exchange of property which could lead to possessions of a material object or an everlasting usufruct. ${ }^{7}$ The reasoning behind the requirement for a sold item to be a material object is that sale contract has the meaning of permanent ownership of the sold item, which differentiates it from lease contract (ijärah). That is the reason why the Shāfi 'i school regarded the sale of a permanent usufruct a valid sale contract.

It is also important to demonstrate that the Muslim jurists set a condition for an item to be accepted as a valid subject matter of a sale contract that it has to be a property. This explains why they did not address the contract of marriage as a sale contract.

The Hanbali scholars discuss this with greater depth and clarity compared to the Shäfi is. In legalising the sale of the usufruct and not considering the sold item to be a necessary material object, they defined a sold item as a property or any permissible usufruct, and also identified property as anything that includes a material object or usufruct. ${ }^{8}$ We can understand that some scholars emphasised on a reservation that the subject matter of a sale contract has to be a material object, even though there are others who opine the legality of the sale of an everlasting 
usufruct. The Hanbali school legalises the sale of the usufruct disregarding whether it is everlasting or not. ${ }^{9}$

\section{CLASSIFICATIONS OF RIGHTS}

Right (haqq) is classified into different types. It can be classified according to the owner of the rights into three types. Firstly, the rights of the Almighty Allah, such as Imān (faith), or something related to the public usage which could not be claimed by anyone but the Almighty Allah. This is called haqq-Allah in order to show that no human being has the right to hold or prevent it to others. ${ }^{10}$ Secondly, rights of human, or right that is privately owned by a person and could not be taken away by any one. Thirdly, interrelated rights of Allah and human beings, and this is divided into two, namely the interrelated rights where the right of Allah is more dominant such as hadd al-zina and the interrelated right where the right of human beings is more dominant, ${ }^{11}$ such as qișa $\bar{s}$.

Imām al-Qarāfî is of the opinion that all the rights of human beings are under the right of Allah, because all rights originated from Allah (SWT). He said there are rights of Allah where you cannot find the right of human beings in them, but there is no right of human beings without a right of Allah in it. ${ }^{12}$ Imām al-Shātịīi also said: there is no Shari'ah ruling which is not related to the rights of Allah, it is a component for worshiping Allah, if a right is given to a person, it is his right that dominates, but it must have connection to the right of the Almighty Allah. ${ }^{13}$

Right could also be classified according to its content into two types namely; financial rights (huqūq māliyyah) and non-financial rights. Financial rights are rights related to $m \bar{a} l$ or property, which is the category mentioned by Prophet Muhammad (peace be upon him) in ahadìth: "Whoever leaves a $m \bar{a} l$ (wealth) or haqq (right), it belongs to his successors." ${ }^{14}$ These types of huquq are numerous, such as the right to ownership of tangible assets, debt, usufruct, right to shuf'ah (pre-emption), easement, right of a person to a will, right to reclaim the willed asset, and right to the bounty of war after taking possession, although the war combatants according to the Hanafi school have no right to possession prior to the distribution of the bounty. ${ }^{15}$ However scholars from the Shāfi'i school of jurisprudence are of the opinion that the war combatants will have the right to possess (tamalluk) before the distribution, therefore they can say that they possessed their portion from the bounty, although they will only have the right of milk (ownership) after the distribution. ${ }^{16}$ Imām Ahmad ibn Hanbal is of the opinion that the bounty of war will be automatically owned by the combatant as soon as the property is freed from the hands of their opponents. ${ }^{17}$

Non-financial rights are the rights which are not connected to wealth or property. Examples of such include the rights of the relatives of a murder victim to retaliate, 
their right to pardon the killer and the right to child custody (hadānah). Our main concern here is the right of human beings which is related to the $m \bar{a} l$ (wealth). Imām Ibn Rajab from the Hanbali school classified the rights of human-beings into five as follows: rights of possession (haqq al-milk), rights of taking over (haqq tamalluk), right to usufruct (haqq al-intifāq), right to exclusion (haqq al-ikhtișāss) and right for the redemption of property (haqq muta 'alliq bistifä'il haq). ${ }^{18}$

Haqq al-milk, can be classified into two, namely complete and partial ownership (tâm and nāqiș). The complete ownership or milk al-tām is defined as possessing the complete asset including the material object and the usufruct, so that the owner will have all the rights associated with the asset. ${ }^{19}$ One of the milk al-tam components is that it is an absolute and permanent ownership that could never be taken away from the original owner and it is not subject to withdrawal, as in the case if someone snatched it from the owner and the owner denied its ownership, the subject matter is still his own despite his denial. ${ }^{20}$ However it can accept a change of ownership through the accepted Islamic norms for transfer of ownership such as contract of sale, will or inheritance. The owner has an absolute right to use or invest the subject matter as he likes; he can rent it out, sell it, give it away for free, or bequeath it in his will because he possesses both the material object and the usufruct. ${ }^{21}$

Partial ownership (al-milk al-nāqiṣ) is defined as ownership of either the material object alone or the usufruct alone. ${ }^{22}$ It is called ownership of the usufruct or the right to use; it can be a right for a person to use, meaning that the right is attached to the person and not the subject matter. It can also be attached to the subject matter without considering the owner or the person that should use it. This is called the right of easement (haqq al-irtifāq), which is restricted only for realty. Partial ownership could be classified into two types, namely ownership of the material object alone, meaning that a person can possess the material object while another person owns the usufruct. For example if a person wills his house to another for his entire life, the owner possesses only the house but the house usufruct is owned by the occupant by means of the will. In this case, even if the owner of the house dies, the ownership of the usufruct by will continues until the duration of the will ends as prescribed by the owner or by the death of the occupant upon which the ownership of the usufruct will be transferred to the heirs of the original owner. ${ }^{23}$ The ownership of the material object turns into complete ownership at the end of the will agreement.

Secondly, ownership of the usufruct only. There are four ways of usufruct acquisition, namely borrowing ( ' $i$ 'ärah), lease (ijārah), endowment (waqf) and ibähah. 'I'ärah or borrowing is identified by the Hanafi and Māliki Scholars as free usufruct ownership. The person who receives ownership of the usufruct through borrowing can also lend it to someone else but he cannot lease it to 
anyone, because ' $i$ 'a $\mathrm{arah}$ or borrowing is not a binding contract as the owner can eliminate it at anytime. However, ijārah is a binding contract and a weak contract cannot overcome a strong one. ${ }^{24}$

According to Shāfi 'i and Hanbali schools, 'i 'ärah or borrowing is defined as legal usage of free usufruct; therefore the borrower cannot rent the subject matter to anyone. ${ }^{25}$ However, leasing or ijärah could be identified as possessing the usufruct of the subject matter for a return, the lessee can lease the subject matter to a third party for free or for a return if the usage is identical, but if the usage is not the same then the lessee has to ask the permission of the owner before he can lease it to a third party. As for the usufruct ownership by will, only the target person has the right to the usufruct, however he can pass the usufruct to anyone either for free or for a return subject to the approval of the owner. ${ }^{26}$

Ibāhah simply means to allow or permit someone to utilise from something such as food, drinks and roads. Muslim scholars have agreed that a person who is permitted to use a mubāh , should not have the legal capacity to allow or prevent it to a third party. The difference between milk and mubăh is that, for milk the person who owns something has the right to use and allow others to, but for $m u b \bar{a} h$ he only has the right to use it by himself and does not have the right to allow or prevent others. ${ }^{27}$

Some contemporary Muslim scholars classified right according to its transferability and tradability into three types, namely personal financial right (haqq māli shakhșī), corporeal financial right (haqq māli 'ayni) and financial right on receivables or debt (haqq al-dayn). ${ }^{28}$

The personal financial right ( $h a q q$ mäli shakhṣì) is transferable via inheritance but not tradable. An example of the personal financial right is the right to claim compensation for an injury. This financial right is transferable to the legal heirs but not tradable to a third party. ${ }^{29}$

The corporeal financial right (haqq māli 'ayni) is transferable and tradable to a third party. This financial right is called right to ownership (haqq al milkiyyah), such as shares and intellectual property rights; these rights can be bought and sold to third parties.

Lastly, the financial rights to receivables or debt payments (haqq al-dayn) which are still in the obligation of the debtor (haqq fi dhimmah), These financial rights are transferable and tradable but subject to strict rules related to the nature of the financial rights that are ribÉ-bearing. These financial rights are transferable through inheritance and transfer of debt (hawälah). They are also tradable according to some jurists, but subject to the strict rules on exchange of money for money (sarf). This is because, debt is considered to be similar to money, which is ribü-bearing, and can only be exchanged for the same denomination at par and spot transaction. ${ }^{30}$ 


\section{Easements (Huqūq al-irtifäq)}

Haqq al-Irfäq or al-irtifäq (easement) is defined as a permanent right attached to a tangible property for a shared benefit of another property, ${ }^{31}$ such as water wells, subways, roads, neighborhood and the right of access to tall buildings. The easement rights are restricted in the above mentioned examples by the Hanafi school of jurisprudence, however according to the Māliki school, the rights to easement are not restricted; it can be instigated through a mutual contract. ${ }^{32}$ For example, there might be an agreement that any building in a neighborhood should not exceed a specific height limit, thus creating an easement for residents of that neighbourhood.$^{33}$ Easement is not regarded as $m \bar{a} l$ on its own according to the Hanafi school, because it could not be taken or stored, this is according to their definition of $m \bar{a} l$ and such could not be sold, donated or leased out for money. They regard it as financial right due to its relation with tangibles, then they allowed it to be sold together with the tangibles.

Imām al-Kāsāni illustrated this by reference to water wells attached to a property should not be sold alone, such as to sell a right to drink for one day or another, because drinking is a right and it cannot be bought or sold alone. However, if a land is sold together with the well then it is acceptable. It cannot be leased, because the return of leasing is the same as the return for contract of sale, but it is lawful to lease a house together with its well. ${ }^{34}$ Furthermore, the right to easement as also includes the right to pre-emption ( $\left(s h f^{\prime} a h\right.$ ) which should not be sold in any situation similar to the case of easement because the right to pre-emption is a right attached to property, which is an easement. ${ }^{35}$ However, the Hanafis still regard the right to easement as a financial right even if it is not a $m \bar{a} l$ on its own. Imām Kāsāni said: "A well or a drinking point is not a property but a financial right". 36

However, the majority of the Māliki, Shāfi $i$ and Hanbali scholars are of the opinion that easement is $m \bar{a} l$ on its own and could be donated, sold, or leased out separately. ${ }^{37}$ There is no argument between scholars that the easement rights could not be dropped with the death of the owner, but will be transferred to his successors together with the tangible assets owned by him, because it is a financial right that has the meaning of $m \bar{a} l$ and attached to a tangible asset. Therefore death will not have an influence on its ownership regardless as to whether it is a dependent right or it is $m \bar{a} l$ on its own..$^{38}$ The case study below will demonstrate how financial rights are used as assets in sukük structure. 


\section{CASE STUDY OF SUKĒK STRUCTURE ON RIGHTS (HUQŪQ ASSET)}

In 2012, the Malaysian company "Projek Lebuhraya Usahasama" (PLUS) closed a record breaking landmark RM30.6 billion (US\$9.86 billion) șukūk programme comprising two tranches of government guaranteed and non-government guaranteed 'AAA'-rated issuances of varying tenors, sizes, expected returns and yields to maturity. This sukūk deal is the world largest to date with the largest single issuance from Malaysia. The șukük was based on an Islamic medium term notes ("Șukūk Mushärakah") issuance programme of up to RM23.35 billion in nominal value based on the Islamic principle of Mushärakah ("Sukūk Programme"). In respect of each issue of Sukūk Mushārakah under the Sukūk Programme, PLUS Berhad will identify its business comprising rights under the respective toll-road concessions granted by the government of Malaysia ("GOM") or part thereof which will be used as the underlying asset for that particular Mushärakah transaction. ${ }^{39}$

The potential holders of the Sukūk Mushärakah ("Sukūk holders") shall via the trustee, from time to time, form a Mushärakah amongst themselves, which is a partnership amongst the sukūk holders, to invest (via the trustee) in the underlying asset ("Mushärakah Venture") via the subscription of the Sukük Mushärakah to be issued by PLUS Berhad. PLUS Berhad shall make a declaration that it holds on to the trust, the underlying asset for the benefit of the sukük holders. The Sukük Mushärakah shall represent amongst others, the șukük holders' undivided proportionate interest in the Mushärakah Venture. PLUS Berhad shall receive Mushärakah capital arising from the subscription of the Sukūk Mushärakah, which is equivalent to the proceeds from the Sukūk Mushärakah. There will be at least two Sukūk holders forming the Mushärakah at each issuance. ${ }^{40}$

Any profit or losses derived from the Mushärakah Venture will be distributed or borne by each $s u k \bar{u} k$ holder in proportion to each $S u k \bar{u} k$ holder's respective contribution of the Mushärakah Capital. In respect of Sukūk Mushārakah without periodic distribution, income from the Mushärakah Venture of up to the Expected Return shall be distributed on a one-off basis ("One-off Distribution") upon the maturity date of the Sukūk Mushārakah or the Dissolution Date, whichever is earlier. In the event of any shortfall between the One-off Distribution and the Expected Return for the relevant period, PLUS Berhad shall make top-up payments to make good the difference. The Top-up payment will be set-off against the Exercise Price. Any income in excess of the Expected Return shall be retained by PLUS Berhad as an incentive fee. ${ }^{41}$

At maturity, PLUS Berhad (as the "Obligor") shall undertake to purchase the sukük holders' interest in the Mushärakah Venture by entering into a sale agreement and pay the Exercise Price on either the maturity date of the $S u k \bar{u} k$ 
Mushārakah or on the Dissolution Date, whichever is earlier. PLUS Berhad shall be entitled to set-off the Exercise Price with any top-up payment(s) made. ${ }^{42}$

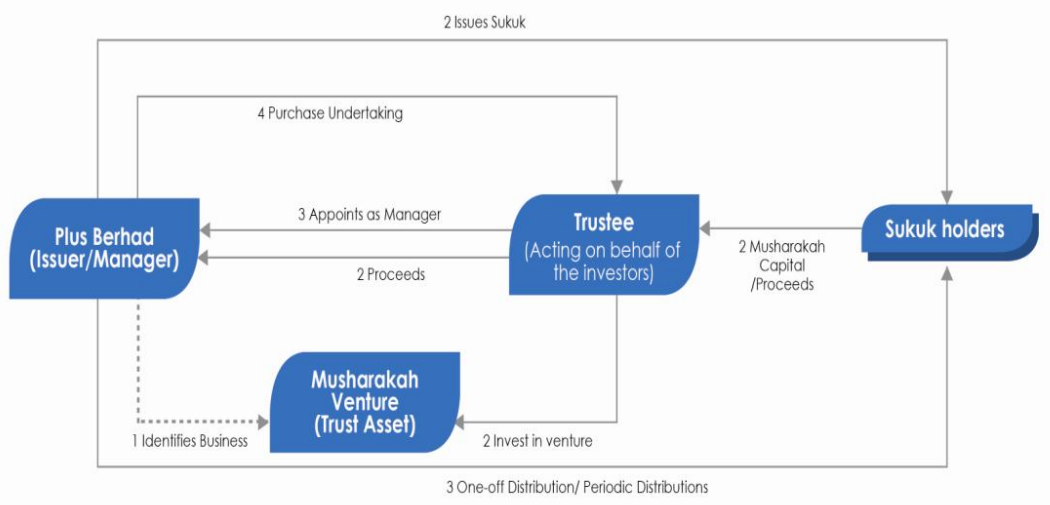

Source: Annexure 1 (PLUS Berhad-Sukuk Programme

Step (1) In respect of each issue of Sukūk Mushärakah under the Sukūk Programme, PLUS Berhad will identify its business comprising rights under the respective toll-road concessions granted by the Government of Malaysia ("GOM") or part thereof which will be used as the underlying asset ("Underlying Asset") for that particular Mushärakah transaction.

Step (2) The potential holders of the Șukūk Mushärakah ("Ṣukūk holders") shall via the Trustee, from time to time, form a mushärakah amongst themselves, which is a partnership amongst the Sukūk holders, to invest (via the Trustee) in the Underlying Asset ("Mushärakah Venture") via the subscription of the Sukūk Mushārakah to be issued by PLUS Berhad. PLUS Berhad shall make a declaration that it holds on trust, the Underlying Asset for the benefit of the Sukūk holders. The Sukūk Mushärakah shall represent amongst others, the șukūk holders' undivided proportionate interest in the Mushärakah Venture. PLUS Berhad shall receive mushārakah capital ("Mushärakah Capital") arising from the subscription of the Sukük Musharakah, which is equivalent to the proceeds from the Sukūk Mushärakah. There will be at least two sukūk holders forming the mushärakah at each issuance.

Step (3) The expected return of the Sukük holders from the Mushärakah Venture "Expected Return" shall be the yield for the Sukūk Mushärakah up to the maturity date of the Sukūk Mushärakah or the date of declaration of an Event of Default/ Dissolution Event ("Dissolution Date"), whichever is the earlier. Pursuant to the management agreement to be entered into between PLUS Berhad and the Trustee (acting on behalf of the șukük holders), the Trustee shall appoint PLUS Berhad as 
the manager of the Mushärakah Venture. In respect of Sukūk Mushärakah with periodic distribution, income from the Mushärakah Venture of up to an amount equal to a certain percentage of the face value of the Sukūk Mushärakah per annum, "Expected Periodic Distribution" shall be distributed periodically in the form of periodic distribution "Periodic Distribution" to the Sukūk holders of that particular Sukūk Mushārakah. The Periodic Distribution shall be made semiannually or such period to be determined prior to each issuance of the Sukük Mushärakah (each such date for distribution, a "Periodic Distribution Date"). In the event of any shortfall between the Periodic Distribution and the Expected Periodic Distribution for such relevant period, PLUS Berhad shall make topup payments to make good the difference. The Top-up payments will be set-off against the Exercise Price (as defined hereinafter). Any income in excess of the Expected Periodic Distribution shall be retained by PLUS Berhad as an incentive fee. In respect of Sukūk Mushärakah without periodic distribution, income from the Mushärakah Venture of up to the Expected Return shall be distributed on a one-off basis ("One-off Distribution") upon the maturity date of the Sukük Musharakah or the Dissolution Date, whichever is the earlier.

In the event of any shortfall between the One-off Distribution and the Expected Return for such relevant period, PLUS Berhad shall make Top-up payment to make good the difference. The Top-up payment will be set-off against the Exercise Price. Any income in excess of the Expected Return shall be retained by PLUS Berhad as an incentive fee.

Step (4) Pursuant to a purchase undertaking granted by PLUS Berhad (as Obligor) in favor of the Trustee (acting on behalf of the sukūk holders) (Purchase Undertaking), PLUS Berhad shall undertake to purchase the sukūk holders' interest in the Mushärakah Venture by entering into a sale agreement ("Sale Agreement") and pay the Exercise Price on either the maturity date of the Sukük Mushärakah or on the Dissolution Date, whichever is earlier. PLUS Berhad shall be entitled to set-off the Exercise Price with any top-up payment(s) made. ${ }^{43}$

There are Shari' $a h$ issues that need to be clarified related to this important sukūk. Firstly, the issue of the asset sold to the sukük holders, the concession right whether it is really sold or the sukük holders have only purchased part of the income receivables of the PLUS companies for a period of time, by way of giving debt to the company for a specific duration of time, which is not lawful according to the majority scholars. However, there are contract rights which are applicable by the Shari'ah, such as giving up one's right to someone for a fee. Most of the recent Hanafi and Shäfi 'i scholars endorsed this idea, and this is the position of the Hanbali school as well. According to this idea, a person can sell his right and step down in favor for another person in exchange of an amount of money. Therefore, according to this argument, PLUS șukūk is a Sharī $a h$ compliant șukük 
because it sells its concession right to investors for money, and the relationship between PLUS and investors is purchase of a Shari '`a compliant intangible right, which is similar to nuzūl 'an al-wază 'if bil māl (waive in exchange for a fee).

Some scholars also argued that this kind of sukūk is valid because it is based on Badal al-kuluwwi. Badal al-kuluwwi is where a person enters into an ijärah agreement for realty for instance, and rents out the usufruct rights to another person and takes a fee for that. Because he owns the usufruct right at that moment, therefore he has the right to sell it to another person. Based on this, PLUS has the right to sell its concession right to investors for money and for a specific duration of time.

Secondly, though the sukūk is based on the mushärakah principle, the Islamic partnership contract, there remains some hurdles challenging the partnership nature of PLUS sukūk. In the sukūk documentation, the PLUS Company undertakes to top up payment where the anticipated profit was not realised by the underlying venture. This act of top up is not a Sharī'ah recognised mechanism, as a mushärakah contract is concerned with profit and loss sharing, which should be determined according to the outcome of the venture. The originator should not act to secure the investors' mandate to maintaining stable income.

\section{CONCLUSIONS/FINDINGS AND RECOMMENDATIONS}

Under Islamic law, the subject matter of şukük transaction has to be a valuable property that is capable of ownership and possession. It is concluded that the view of the majority scholars of the inclusion of rights and usufructs in the meaning of property in Sharī'ah is a preferred view. These rights and usufructs can be termed as financial rights. The view is more flexible and can potentially cover many types of new financial rights, as long as those financial rights can be subjected to ownership, control and exploitation. Malaysian scholars regarded the government awards and concession contracts as valuable assets that are capable of being bought and sold. The basis of the opinion is the analogy between the government award and the concept and practice of $i q t \bar{a}$ ' which is an approved practice in Islamic law. Generally, iqtä' refers to the practice of the head of state (Imām) awarding certain portions of an undeveloped government land to any individual for the purpose of growth exploitation. Iqtä' was practiced by the Prophet Muhammad (peace be upon him) and the prominent companions. For the enhancement of the industry the paper recommends the following:

1. Sukūk market players can make use of right and usufruct as underlying asset for șukūk structure since it is valuable, legal and capable of being possessed or sold. It is also hinted that legal ownership of the right must 
be certain before its incorporation as sukūk underlying asset. All properties with an unlawful usufruct cannot be owned or sold and therefore should not be regarded as sukük asset.

2. Sukūk which underlying asset is government awards or concession agreement should be strictly issued by government entities alone; private entities should not use government awards (iqtä') as asset in their șukūk structure.

3. For mushärakah șukük issuances, it is recommended that there should be a strict adherence to the mushärakah principle that profit must be distributed according to the outcome of the venture. Any act of maintaining stable income for the investors will attract Shari' ah issues and it is a violation of the mushärakah venture principles.

4. Public interest must be established before using a public owned property as sukūk asset.

\section{Notes}

* Auwal Adam Sa'ad acquired his LLB Sharī'ah from Islamic University Madina, Kingdom of Saudi Arabia in 2006. In 2009, he obtained Master of Comparative Laws from Ahmad Ibrahim Kulliyyah of Laws, International Islamic University Malaysia. He is currently a PhD candidate at Ahmad Ibrahim Kulliyyah of Laws, International Islamic University Malaysia. He has being a part time lecturer at the same faculty, and a research assistant at the International Sharī'ah Research Academy (ISRA). His major areas of interest and specialisations are Islamic Commercial law, Islamic Banking and Finance, with special concern on Sukük and Islamic Capital Markets in general. He has authored several articles and attended numerous conferences and attended training of Sharī'ah advisers and experts pioneered by the department of Islamic Capital Markets of the Securities Commission of Malaysia.

1. Huqūq is a plural of Haq and literally means truth or rights although the word $\dot{H} a q$ has various related meaning according to Sharī'ah. The word Haq could be used to mean the name of the Almighty Allah (SWT). Allah the Almighty says: "But if the Truth [i.e, Allah] had followed their inclinations, the heavens and the earth and whoever is in them would have been ruined." Meaning that if the Almighty Allah would follow the inclinations of disbelievers then the world and the heavens would be spoiled. The word Haq could be used to mean the Holy Qur'ān, Allah the Almighty says: "However, I gave enjoyment to these [people of Makkah] and their fathers until there came to them the truth and a clear Messenger" The truth here means the Holy Qur'ān. The word Haq also means Islam, Allah the Almighty said: "And say, the truth has come and falsehood has departed. Indeed is falsehood by nature ever bound to depart." Haq means truth, the Almighty Allah said: "It is the promise of Allah which is truth" Haq means compulsion, Allah the Almighty said: "And if we had 
willed, we could have given every soul its guidance, but the word from me will come into effect that I will surely fill Hell with Jinn and people together," Qur'an Sūrat Mu'minun verse 71, Qur'an Sūrat Az-Zukhruf verse 29, Qur'an Sūrat Al-Isra', verse 81, Qur'an Sūrat As-Sajdah, verse 13, Qur'an Sūrat Yunus, verse 4.

2. Qur'an 2/282.

3. Ahmad bin Idrīs bin Abdurrahman Abul-'Abbās Al-Qarāfī "Kitāb Al-Furūq", Lebanon: Dār al-Gharb, (1994) vol.3 p.209.

4. Muhammad bin 'Alī bin MuÍammad Al-Shaukānī "Fath al-Qadìr", Lebanon: Dār al-Gharb, (1994) vol.5 p.456.

5. Muhammad 'Alā'uddīn Afandī Ibn 'Ābidīn "Hāshiyāt Raddul Mukhtār" Lebanon: Dār al-Fikr li’n Nashr, (2000) vol.4 p.50-51.

6. Majallat Majma' al-Fiqh al-Islāmī, Maktabat al-Shāmilah, vol.5 p.2035.

7. Ibid., vol.5 p.2036.

8. Shamsuddīn Abu Bakr bin Abū Sahl Al-Sarkhasī “Al-Mabsūṭ", Lebanon: Dār al-Fikr li’n Nashr, (2000) vol.11 p.78.

9. Ibid.

10. Majallat Majma' al-Fiqh Al-Islāmī, Maktabat al-Shāmilah, vol.5 p.1866.

11. Ibid., vol.4 p.1754.

12. Ahmad bin Idrīs bin Abdurrahman Abul-'Abbās Al-Qarāfī, "Kitāb Al-Furūq" Lebanon: Dār al-Gharb, (1994) vol.1 p.141.

13. Ibrāhīm bin Mūsā bin Muhammad al-Lakhmī al-Shātibī, "Al-Muwāfaqāt fi Usulil Ahkām" Giza: Dār Ibn Iffān, (1997) vol.2 p.333.

14. Muhammad bin Ismāēil Al- Bukhārī, "Kitāb al-Jāmi' al-Ṣahịh" al-Hawālāt Cairo: Dār al-Nashr, (1987) hadīth no. 2175 and Muslim, "Kitāb Jāmi' alȘahịh" al-Farā'idh, Beirut: Dār al-Jīl, and Dār al-’ Āfāq al-Jadīdah, ḥadīth no. 1619, both via Maktabat al-Shāmilah.

15. Majallat al-Buhūth al-Islämiyyah, Kingdom of Saudi Arabia: Ar-Ri'āsah alĀmmah lil-Buhuth al-'Ilmiyyah wal-'Ifta', (1994) vol.40, p.362.

16. Ibid.

17. Abdullah bin Ahmad bin Qudāmah al-Maqdisī “Al-Mughnĭ’, Lebanon: Dar al-Fikr (1984) vol.9 p.238.

18. Imām Al-Shātibī, "Al-Muwāfaqāt fi Uṣulil Aḥkām”, Dār Ibn 'Affān (1997) vol.2 p.333.

19. Wahbah Al-Zuhailī, "Al-Fiqh al-Islāmī wa Adillatuh”, Syria, Damascus: Dār al-Fikr, vol.4 p.414.

20. Ibid.

21. Ibid.

22. Ibid.

23. Ibid., p.415.

24. Ibid., p.416.

25. Ibid.

26. Ibid., p.417.

27. Ibid.

28. Engku Rabiah Adawiah Engku Ali, Islamic Law Issues in Sale-Based Financing Structures as Practiced in Malaysia, "Essential Readings in Islamic Finance", Kuala Lumpur: Centre for Research and Training, (2008) p.550. 
29. Ibid.

30. Another classification of haqq according to personal rights (Shakhșī) or AlIltizām and right in rem, (Aini), personal rights or Al-Iltizām are rights related to a person in which someone is oblige to compensate, repay, work or deny working for another person. Right in rem is an authority given by law over a particular property. Sheikh al-Sanhūrì demonstrated that the terms personal rights and rights in rem were not originally known by Muslim Jurists, it is a terminology imported from western jurisprudence. Muslim Jurists used the word right $(h a q)$ to mean all financial and non-financial rights; they differentiate the right of Allah and the right of human beings, and they use the word $(H u q \bar{u} q)$ to mean easement right in some occasions. Haq Shaksī or AlIltizām has four different legal connotations as follows. Firstly: Commitment to Debt, (Al-Iltizām Bil-Dayn) is a commitment on certain amount of money or property to be paid by a debtor. Debt could be initiated either by contract, contract of sale and a personal initiative such as al-Nazar (to swear) al-Hibah (gift) or wasiyyah (will).

31. Majallat Majma' al-Fiqh Al-Islāmī, Maktabat al-Shāmilah, vol.4, p.826.

32. Abdul-Razzāq al-Sanhūri, "Maṣādir al-Haq fil-Fiqh al-Islāmì̄", Dār al-Hanā, Cairo, (1954) vol.1, p.30.

33. Majallat Majma' al-Fiqh Al-Islāmī, Maktabat al-Shāmilah, vol.4, p.826.

34. Abdulsalam Dawud Al-Abādī, "Al-Mulkiyyah fil-Sharī'ah al-Islämiyyah" Mu'assasat al-Risālah, Damascus, vol.1 p.221.

35. Ibid.

36. Abū Bakr bin Mas'ūd bin Ahmad al-Kāsānī, "Badā'i' al-Sanā'i' fì Tartīb alSharā'i $i$, Dār al-Hadīth, Cairo (2005) vol.8, p.297.

37. 'Uthmān bin 'Alī bin Mahjin al-Zaila'ī, "Tabyīn al-Haqā'iq fì Sharh Kanz alDaqā'iq" Maktabat al-Shāmilah vol.11, p.194.

38. Al-Mausū'àt al-Fiqhiyyah al-Kuwaitiyyah, Wizārat al-Awqāf wa-l Shu'ūn alIslāmiyyah, Kuwait (2000) vol.39, p.264.

39. PLUS Sukūk Principal Terms and Conditions 2012, p.2.

40. Ibid., p.3.

41. Ibid., p.7.

42. Ibid., p.7.

43. Ibid., p.33 


\section{References}

'Abd Allāh ibn Aḥmad ibn Muḥammad ibn Qudāmah Al-Maqdisī, "Al-Mughnĭ (2004). Dār al-Ḥadìth, Cairo.

Abdul-Razzāq al-Sanhūri, "Maṣādir al-Haq fil-Fiqh al-Islāmä” (1954) Dār al-Hanā, Cairo.

Abdulsalam Dawud Al-Abādī, "Al-Mulkiyyah fil-Sharī‘ah al-Islāmiyyah" (2000) Mu'assasat al-Risālah, Damascus, Syria.

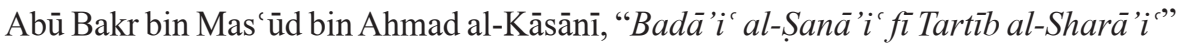
(2005) Dār al-Hadìth, Cairo.

Abul-Hasan Muslim Bin al-Hajjāj bin Muslim al-Qushairī al-Naisabūrī "Kitāb Jāmi al-Sahīḥ" Dār al-Jīl, Beirut, and Dār al-'Āfāq al-Jadīdah, via Maktabat al-Shāmilah.

Aḥmad bin Idrīs bin 'Abdurraḥmān Abul- 'Abbās Al-Qarāfî, "Kitāb Al-Furūq" (1994) Dār al-Gharb, Lebanon.

Engku Rabiah Adawiah Engku Ali, "Essential Readings in Islamic Finance”, (2008) Centre for Research and Training, Kuala Lumpur.

Ibrāhīm bin Mūsā bin Muhammad al-Lakhmī al-Shāṭibī, "Al-Muwāfaqāt fi Uṣulil Ahkām” (1997) Dār Ibn 'Affān, Giza, Egypt.

Majallat al-Buhūth al-Islāmiyyah, (1994) Ar-Ri'āsah al-Āmmah lil-Buhuth al'Ilmiyyah wal-'Ifta', Kingdom of Saudi Arabia.

Majallat Majma al-Fiqh Al-Islāmī, via Maktabat al-Shāmilah.

Al-Mausū'āt al-Fiqhiyyah al-Kuwaitiyyah, (2000) Wizārat al-Awqāf wa-l Shu'ūn alIslāmiyyah, Kuwait.

Muhạmmad 'Alā'uddīn Afandī Ibn Abidīn, "Hāshiyāt Raddul Mukhtār" (2000) Dār al-Fikr li’n-Nashr, Lebanon.

Muḥammad bin 'Alī bin Muḥammad Al-Shaukānī, "Fath Al-Qadīr" (1994) Dār alGharb, Lebanon.

Muḥammad bin Ismā‘ īl bin Ibrāhīm bin Mughīrah Al-Bukhārī, "Kitāb Al-Jāmi alȘahịh" (1987) Dār al-Nashr Cairo, via Maktabat al-Shāmilah.

Shamsuddīn Abu Bakr bin Abū Sahl Al-Sarkhasī, "Al-Mabsūṭ" (2000) Dār al-Fikr li'n-Nashr, Lebanon.

Wahbah Al-Zuhaylī, “Al-Mu'āmalāt Al-Mãliyyah Al-Mu'āșirah” (2002). Dār al-Fikr Al-Mu'āșir, Beirut, Lebanon.

Wahbah Al-Zuhaylī, “Al-Fiqh al-Islāmī wa Adillatuh” Dār al-Fikr, Damascus, Syria. 